\title{
Outdoor air pollution and respiratory health in patients with COPD
}

\author{
Janet L Peacock, ${ }^{1}$ H Ross Anderson, ${ }^{2}$ Stephen A Bremner, ${ }^{3}$ Louise Marston, ${ }^{4}$ \\ Terence A Seemungal, ${ }^{5}$ David P Strachan, ${ }^{2}$ Jadwiga A Wedzicha ${ }^{5}$
}

\begin{abstract}
- Additional tables and methods are published online only. To view these files please visit the journal online (http:// thorax.bmj.com).

1 Department of Primary Care and Public Health Sciences, King's College London, London, UK

${ }^{2}$ Department of Community Health Sciences, St George's, University of London, London, UK

${ }^{3}$ Queen Mary University of London, Barts and the London School of Medicine and Dentistry, Centre for Health Sciences, Whitechapel, London, UK

${ }^{4}$ Department of Primary Care and Population Health, University College London, London, UK

${ }^{5}$ Academic Unit of Respiratory Medicine, University College London Medical School, London, UK
\end{abstract}

\section{Correspondence to}

Professor Janet L Peacock, Department of Primary Care and Public Health Sciences, King's College London, 7th Floor Capital House, 42 Weston Street, London SE1 30D, UK; janet.peacock@kcl.ac.uk

Received 10 November 2010 Accepted 24 February 2011

Published Online First

1 April 2011

\section{ABSTRACT}

Objectives Time series studies have shown adverse effects of outdoor air pollution on mortality and hospital admissions in patients with chronic obstructive pulmonary disease (COPD) but panel studies have been inconsistent. This study investigates short-term effects of outdoor nitrogen dioxide, ozone, sulfur dioxide, particulate matter $\left(\mathrm{PM}_{10}\right)$ and black smoke on exacerbations, respiratory symptoms and lung function in 94 patients with COPD in east London.

Methods Patients were recruited from an outpatient clinic and were asked to complete daily diary cards (median follow-up 518 days) recording exacerbations, symptoms and lung function, and the amount of time spent outdoors. Outdoor air pollution exposure (lag 1 day) was obtained from local background monitoring stations.

Results Symptoms but not lung function showed associations with raised pollution levels. Dyspnoea was significantly associated with $\mathrm{PM}_{10}$ (increase in odds for an IOR change in pollutant: $13 \%(95 \% \mathrm{Cl} 4 \%$ to $23 \%))$ and this association remained after adjustment for other the pollutants measured. An IOR increase in nitrogen dioxide was associated with a $6 \%(0-13 \%)$ increase in the odds of a symptomatic fall in peak flow rate. The corresponding effect sizes for $\mathrm{PM}_{10}$ and black smoke were $12 \%(2-25 \%)$ and $7 \%(1-13 \%)$, respectively. Conclusion It is concluded that outdoor air pollution is associated with important adverse effects on symptoms in patients with COPD living in London.

\section{INTRODUCTION}

Chronic obstructive pulmonary disease (COPD) is increasing in incidence worldwide and is currently the sixth leading cause of death. ${ }^{1}$ Patients with COPD are prone to acute deterioration in their chronic symptoms. These exacerbations of COPD were first shown to be associated with air pollutants during the London smog episode of $1952 .^{2}$ There is now clear evidence that air pollution at current levels in London affects mortality ${ }^{3} 4$ and that air pollution levels in Europe lead to hospital admissions for COPD. ${ }^{5}$

Panel studies have shown adverse effects at relatively low levels of pollution. One of the earliest panel studies in patients with COPD showed that changes in pollution level were associated with exacerbations of chronic bronchitis. ${ }^{6}$ A study in Merseyside, UK involving 75 patients with COPD reported effects of ozone $\left(\mathrm{O}_{3}\right)$ and sulfur dioxide $\left(\mathrm{SO}_{2}\right)$ on peak expiratory flow (PEF) and respiratory symptoms recorded daily using diary

\section{Key messages}

What is the key question?

- Does outdoor air pollution affect exacerbations, respiratory symptoms and lung function in patients with COPD?

What is the bottom line?

- In patients with COPD living in London, there is evidence for adverse effects of outdoor pollution on symptoms and exacerbations, particularly for $\mathrm{PM}_{10}$, black smoke and $\mathrm{NO}_{2}$.

\section{Why read on?}

- Ecological studies have shown links between outdoor air pollution and increased COPD mortality/morbidity and this study shows similar effects in individual patients, supporting the case for causality.

cards. ${ }^{7}$ A Dutch panel study similarly reported adverse effects of $\mathrm{PM}_{10}$ (particulate matter), black smoke, sulfate and $\mathrm{SO}_{2}$ on PEF, and effects of black smoke on upper respiratory symptoms in 326 symptomatic adults. ${ }^{8}$ A panel study in Italy reported adverse effects of particles and nitrogen dioxide $\left(\mathrm{NO}_{2}\right)$ on forced vital capacity (FVC) and forced expiroatory volume in $1 \mathrm{~s}\left(\mathrm{FEV}_{1}\right)$ in 29 subjects with COPD, ${ }^{9}$ and similar associations between $\mathrm{FEV}_{1}$ and particles were reported in a US COPD panel with 24 subjects. ${ }^{10}$ A New Zealand COPD panel study in 48 patients found no effect of pollution levels on PEF but observed effects of particles on night-time symptoms and nebuliser use. ${ }^{11}$ A French study conducted at a similar time to the present study analysed effects of air pollution on COPD exacerbations and reported adverse effects of $\mathrm{O}_{3}{ }^{12}$

In this paper we examine the effects of a range of air pollutants on COPD exacerbations, respiratory symptoms and respiratory function, including large decrements in PEF, in a panel of 94 patients with moderate to severe COPD selected from a COPD clinic in London and followed over a 2-year period, October 1995-October 1997.

\section{METHODS \\ Subjects}

The East London COPD study was established in 1995 as a prospective study of the role of viral infections and environmental factors in COPD exacerbations. ${ }^{13-16}$ Subjects were patients with 
moderate to severe COPD attending an outpatient clinic at the London Chest Hospital, London. Recruitment was from October 1995 to October 1997. Inclusion criteria were: $\mathrm{FEV}_{1}<70 \%$ predicted for age and height, $\beta 2$-agonist reversibility $<15 \%$ or $200 \mathrm{ml}^{17} 18$ and no exacerbations in the previous 4 weeks. Exclusion criteria were asthma, bronchiectasis, carcinoma of the bronchus or inability to complete diary cards. Patients were seen at the clinic monthly during the colder months and 3-monthly during the rest of the year. Patients were also seen acutely at exacerbation and then at a convalescent visit 4-6 weeks postexacerbation.

\section{Data collected}

At recruitment, baseline measurements were made of height, weight, $\mathrm{FEV}_{1}, \mathrm{FVC}$ and PEF by rolling seal spirometer (Sensor Medic, Yorba Linda, California, USA), reversibility to $400 \mu \mathrm{g}$ of inhaled salbutamol, and arterialised earlobe blood gases. ${ }^{19}$ Patients recorded symptoms and lung function daily on diary cards. Patients measured PEF indoors after morning medication using a Mini-Wright peak flow meter (Clement Clarke International, Harlow, UK). They recorded any increase in chronic symptoms during the previous $24 \mathrm{~h}$. Symptoms were categorised as major (dyspnoea, sputum purulence, sputum amount) or minor (nasal discharge/congestion, wheeze, sore throat, cough). Patients recorded bedroom temperature on waking using a $1^{\circ} \mathrm{C}$ Thermax temperature strip (Thermographic Measurements, Burton, UK). From March 1996 onwards, patients recorded the number of hours spent outdoors. FEV 1 and FVC were also measured in a subsample of 28 patients using a handheld spirometer (Micro Medical, Rochester, UK). At the outset of the study, patients were taught how to measure and record lung function and symptoms, and were reminded and/or re-educated when they visited the clinic.

\section{Exacerbations}

Patients were asked to attend clinic if their symptoms worsened. Exacerbations were identified by symptoms recorded on the diary cards or from the history when patients presented to the physician (TAS), according to the criteria modified from Anthonisen et $a l^{20}$ of any two major symptoms or one major and two minor symptoms on two consecutive days. ${ }^{13}$ The first of the 2 days was taken as the onset of the exacerbation. Symptoms present continuously for $>5$ days prior to the possible onset of an exacerbation were discounted. Patients experiencing an exacerbation were given appropriate medication.

A less severe but more common form of exacerbation was also defined a priori as a fall in PEF of $10 \mathrm{l} / \mathrm{min}$ for $\geq 2$ days plus a reported increase in dyspnoea. This was termed a 'symptomatic fall in PEF'. The rationale for using this is that patients with COPD, particularly frequent exacerbators, have high psychosocial and depression scores ${ }^{13}$; however, the presence of symptoms together with a change in lung function is more suggestive of an airway effect than psychological effects.

\section{Outdoor air pollution data}

Hourly measurements of $\mathrm{NO}_{2}, \mathrm{O}_{3}, \mathrm{SO}_{2}$ and $\mathrm{PM}_{10}$ were obtained from the national air quality monitoring network station at Bloomsbury Square, central London via the UK National Air Quality Information Archive (http://www.airquality.co.uk/). At the time of the study this was the only monitoring station in London for these pollutants. The following pollutant measures were derived: maximum hourly $\mathrm{NO}_{2}$, maximum $8 \mathrm{~h}$ moving average $\mathrm{O}_{3}, 24 \mathrm{~h}$ mean $\mathrm{SO}_{2}$ and $\mathrm{PM}_{10}$. The completeness criterion was the availability of at least $75 \%$ of the data used to calculate the summary measure for each day. The $\mathrm{PM}_{10}$ data from this monitor are very closely correlated with the North Kensington site data for the same period $(\mathrm{r}=0.95)$ and so it was reasonable for the Bloomsbury data to represent background levels. For black smoke there was a network of monitors at that time (unlike for other pollutants) and so we used $24 \mathrm{~h}$ average black smoke data from the monitor nearest each patient's home. Missing pollution data were imputed using a standard method. ${ }^{21}$ We chose a priori to analyse 1 day lags (previous day) for all pollutants based on the results of time series studies available at the time.

\section{Statistical methods}

Brief details of statistical methods and rationale are given here, but fuller details are given in the online supplement. Symptoms and exacerbations were analysed as binary incidents - that is, the first day of an episode was the 'event'. To distinguish between new episodes of symptom worsening and the continuation of a current episode, a new episode was recorded when that symptom was not recorded in the previous 7 days.

Generalised estimating equations (GEEs) were used for analysis, taking account of variation within and between individuals. Effects of each symptom or exacerbation were modelled separately, with each pollutant level in turn as the main explanatory variable. Control was made for daily temperature (average of minimum and maximum) and season (analysed in four groups-spring, summer, autumn and winter), with estimates of variance robust against misspecification of correlation structure, which was assumed to be independent. Results were obtained as ORs and 95\% CIs.

All lung function data (PEF, $\mathrm{FEV}_{1}$ and FVC) were analysed as deviations from the individual mean to allow for variation between individuals. Lung function data were analysed in three ways. First they were analysed by season and year (4 seasons $\times 2$ years) to investigate seasonal effects, adjusting for indoor temperature and time spent outdoors using methodology described in previous reports. ${ }^{22} 23$ Secondly, they were analysed using GEEs with Normal errors to summarise effects across the entire time period. Analyses used a first-order autoregressive correlation structure and controlled for temperature and season as described above for symptoms. In addition, a linear time term was included to allow for decline in lung function. Thirdly, lung function was analysed as a binary variable following the method of Hoek. ${ }^{24}$ For each patient, an adverse event, 'large peak flow decrement', was defined if lung function was $>20 \%$ below that individual's median value. These binary events were also modelled using GEEs as described above for the symptom data.

Some associations were observed for effects of single pollutants on certain symptoms and so we decided post hoc to fit selected multipollutant models to try to disentangle these effects and aid interpretation.

All effect estimates are presented in two ways: (1) representing a unit change in pollutant level ( $\mathrm{ppb}$ or $\mu \mathrm{g} / \mathrm{m}^{3}$ as appropriate) and (2) scaled to an IOR change in that pollutant level to aid interpretation. All analyses used Stata v11.

\section{RESULTS}

\section{Summary statistics for subjects and exposure data}

A total of 125 patients were recruited, of whom 31 were excluded for the following reasons: not continuously resident in London (13), in the study for $<3$ weeks (10), patient errors in data recording (1), misplaced diary sheets (1), dementia (1), asthma (1), precancerous illness (1), psychiatric disorder (1) and died (2). Median duration of follow-up was 518 days (range 21-709). Shortened length of follow-up was due to either late 
recruitment, moving away or death. Fifteen patients had their series of measurements truncated as it was suspected that use of the measuring instrument was unreliable during the first few weeks. Further patient characteristics are reported in table 1 and show that the series predominantly comprised older males with obstructive lung disease. Mean numbers of symptoms over the period varied considerably among individuals but were on average quite low, suggesting that the condition of some patients was reasonably stable. Mean values for pollutants were: $\mathrm{NO}_{2} 1 \mathrm{~h}$ max, $51.4 \mathrm{ppb} ; \mathrm{O}_{3} 8 \mathrm{~h}$ average, $15.5 \mathrm{ppb} ; \mathrm{SO}_{2} 24 \mathrm{~h}$ average, $7.5 \mathrm{ppb} ; \mathrm{PM}_{10} 24 \mathrm{~h}$ average, $37.7 \mu \mathrm{g} / \mathrm{m}^{3}$; black smoke $24 \mathrm{~h}$ average, $10.1 \mu \mathrm{g} / \mathrm{m}^{3}$ (table 2). Data from eight different black smoke monitors were used although the majority of patients $(63 \%)$ lived nearest to one monitor (Stepney), which was close to the hospital.

\section{Effects on lung function}

When lung function was analysed by season, very few statistically significant effects were observed. There was a significant adverse effect of $\mathrm{O}_{3}$ on PEF in summer 1996 but not in summer 1997. For $\mathrm{FEV}_{1}$, there was one significant association for $\mathrm{SO}_{2}$ in spring 1996 but this was not replicated the following year. For FVC, significant negative associations were observed for $\mathrm{NO}_{2}$, $\mathrm{PM}_{10}$ and black smoke in summer 1996 and $\mathrm{SO}_{2}$ in spring 1996, but none of these seasonal effects was replicated in 1997 (tables E1-E3 in the online data supplement).

These non-significant findings were confirmed when lung function was analysed over the 2 years combined (table 3 ). Most regression coefficients were positive not negative, and one (PEF and $\mathrm{NO}_{2}$ ) was statistically significant. There was no consistency in findings for PEF, $\mathrm{FEV}_{1}$ and $\mathrm{FVC}$, again providing no support for any adverse effect of pollution on mean respiratory function (table 3 ). There was no evidence for effects of any pollutant on

Table 1 Summary statistics for respiratory data October 1995-October 1997

\begin{tabular}{|c|c|c|c|c|c|}
\hline & $\mathbf{n}$ & Mean (SD) or \% & Median & Minimum & Maximum \\
\hline Male sex & 94 & $72 \%$ & & & \\
\hline Age (years) & 94 & $67.5(8.2)$ & 68.2 & 40 & 83 \\
\hline PEF (I/min) & 94 & $224(79)$ & 220 & 60 & 453 \\
\hline $\mathrm{FEV}_{1}(\mathrm{ml})$ & 28 & $967(363)$ & 880 & 355 & 1731 \\
\hline FVC (ml) & 28 & $1952(762)$ & 2010 & 690 & 3782 \\
\hline Reversibility & 91 & $6.5(10.2)$ & 5.3 & -31 & 37 \\
\hline $\begin{array}{l}\text { Mean no. of large PEF } \\
\text { decrements* }\end{array}$ & 94 & $14(26)$ & 2.5 & 0 & 122 \\
\hline Mean no. of exacerbations & 94 & $3.1(3.2)$ & 2 & 0 & 16 \\
\hline $\begin{array}{l}\text { Mean no. of symptomatic } \\
\text { falls in PEF† }\end{array}$ & 94 & $3.7(3.7)$ & 2.5 & 0 & 16 \\
\hline $\begin{array}{l}\text { Mean no. of episodes of } \\
\text { dyspnoea } \neq\end{array}$ & 94 & $5.7(5.4)$ & 3.5 & 0 & 20 \\
\hline $\begin{array}{l}\text { Mean no. of episodes of } \\
\text { change in sputum } \S\end{array}$ & 94 & $2.9(3.4)$ & 2 & 0 & 17 \\
\hline $\begin{array}{l}\text { Mean no. of episodes } \\
\text { of nasal discharge/ } \\
\text { congestion }\end{array}$ & 94 & $2.9(3.6)$ & 2 & 0 & 19 \\
\hline $\begin{array}{l}\text { Mean no. of episodes } \\
\text { of wheeze }\end{array}$ & 94 & $3.8(4.5)$ & 2 & 0 & 18 \\
\hline $\begin{array}{l}\text { Mean no. of episodes } \\
\text { of URS** }\end{array}$ & 94 & $2.7(3.0)$ & 2 & 0 & 14 \\
\hline \multicolumn{6}{|c|}{$\begin{array}{l}\text { *Large PEF decrements: PEF }<20 \% \times \text { median value. } \\
\text { †Symptomatic fall in PEFs: defined as fall in PEF } 10 \mathrm{l} / \mathrm{min} \text { for } \geq 2 \text { days }+ \text { increase in } \\
\text { breathlessness. } \\
\text { †Dyspnoea: defined as an increase in symptom. } \\
\text { §Sputum changes: defined as a change in sputum purulence or amount. } \\
\text { TWheeze: defined as an increase in wheeze or increase in tightness of chest. } \\
\text { **URS: upper respiratory symptoms-increase in sore throat or cough. }\end{array}$} \\
\hline
\end{tabular}

Table 2 Summary statistics for pollutants and meteorological data October 1995-October 1997

\begin{tabular}{|c|c|c|c|c|c|}
\hline & \multirow{2}{*}{$\begin{array}{l}\text { All months } \\
\text { Mean (SD) } \\
\text { [median] IOR }\end{array}$} & \multicolumn{2}{|c|}{$\begin{array}{l}\text { Autumn and } \\
\text { winter }\end{array}$} & \multicolumn{2}{|c|}{$\begin{array}{l}\text { Spring and } \\
\text { summer }\end{array}$} \\
\hline & & Mean & Range & Mean & Range \\
\hline $\mathrm{NO}_{2}(1 \mathrm{~h} \max , \mathrm{ppb})$ & $\begin{array}{l}51.4(15.8), \\
{[48], 42 \text { to } 56}\end{array}$ & 51.3 & 26 to 163 & 51.5 & 24 to 131 \\
\hline $\mathrm{O}_{3}(8 \mathrm{~h}$ ave, $\mathrm{ppb})$ & $\begin{array}{l}15.5(10.7) \\
{[14.1], 7.5 \text { to } 21.6}\end{array}$ & 9.8 & 1 to 32 & 21.6 & 3 to 74 \\
\hline $\mathrm{SO}_{2}$ (24 h ave, ppb) & $\begin{array}{l}7.5(6.3), \\
{[5.3], 3.2 \text { to } 9.3}\end{array}$ & 9.8 & 1 to 42 & 5.5 & 1 to 74 \\
\hline $\mathrm{PM}_{10}\left(24 \mathrm{~h}\right.$ ave, $\left.\mu \mathrm{g} / \mathrm{m}^{3}\right)$ & $\begin{array}{l}37.7(17.4), \\
{[32.5], 25.9 \text { to } 44.9}\end{array}$ & 39.1 & 10 to 134 & 35.6 & 13 to 86 \\
\hline $\begin{array}{l}\text { Black smoke* } \\
\left(24 \mathrm{~h} \text { ave, } \mu \mathrm{g} / \mathrm{m}^{3}\right)\end{array}$ & $\begin{array}{l}10.1(9.7) \\
{[7], 4 \text { to } 13}\end{array}$ & 12.9 & 1 to 81 & 7.0 & 1 to 34 \\
\hline $\begin{array}{l}\text { Outdoor temperature } \\
\text { (average of min and } \\
\max ,{ }^{\circ} \mathrm{C} \text { ) }\end{array}$ & $\begin{array}{l}11.4(6.0), \\
{[11],-1.5 \text { to } 27}\end{array}$ & 8.1 & -1.5 to 21 & 15.3 & 4.5 to 27 \\
\hline
\end{tabular}

${ }^{*}$ Summary statistics presented for the Stepney black smoke monitor used for $63 \%$ of patients.

PM, particulate matter

large PEF decrements (table 4), with all ORs close to 1.0 and non-significant.

\section{Effects on exacerbations and symptoms}

All ORs for effects of pollutants on exacerbations were $>1.0$, suggesting adverse effects, but all were non-significant (table 4). Effect sizes were bigger for symptomatic fall in PEF where $\mathrm{PM}_{10}$ and black smoke showed significant adverse effects. The remaining $\mathrm{ORs}$ for $\mathrm{NO}_{2}, \mathrm{O}_{3}$ and $\mathrm{SO}_{2}$, while not significant, were nonetheless consistently $>1.0$. ORs for a symptomatic fall in PEF for a change in pollutant level equivalent to the IOR were $1.12\left(95 \%\right.$ CI 1.02 to $\left.1.25, \mathrm{PM}_{10}\right)$ and 1.07 (1.01 to 1.13 , black smoke). Dyspnoea was significantly associated with $\mathrm{PM}_{10}(\mathrm{OR}$

Table 3 Regression of respiratory function (PEF, FEV 1 and FVC) on pollutant level* (previous day)

\begin{tabular}{|c|c|c|c|}
\hline & $\begin{array}{l}\text { Estimate† (per unit } \\
\text { change) }(95 \% \mathrm{Cl})\end{array}$ & p Value & $\begin{array}{l}\text { Estimate } \neq \text { (per } \\
\text { IQR change) }\end{array}$ \\
\hline \multicolumn{4}{|l|}{$\operatorname{PEF}(1 / \min ) n=94$} \\
\hline $\mathrm{NO}_{2}(\mathrm{ppb})$ & $0.013(0.002$ to 0.024$)$ & 0.026 & 0.179 \\
\hline $\mathrm{O}_{3}(\mathrm{ppb})$ & $-0.015(-0.039$ to 0.009$)$ & 0.229 & -0.211 \\
\hline $\mathrm{SO}_{2}(\mathrm{ppb})$ & $0.031(-0.010$ to 0.072$)$ & 0.133 & 0.191 \\
\hline $\mathrm{PM}_{10}\left(\mu \mathrm{g} / \mathrm{m}^{3}\right)$ & $0.009(-0.006$ to 0.023$)$ & 0.253 & 0.164 \\
\hline Black smoke $\left(\mu \mathrm{g} / \mathrm{m}^{3}\right)$ & $0.011(-0.005$ to 0.028$)$ & 0.180 & 0.103 \\
\hline \multicolumn{4}{|l|}{$\mathrm{FEV}_{1}(\mathrm{ml}) \mathrm{n}=28$} \\
\hline $\mathrm{NO}_{2}(\mathrm{ppb})$ & $0.005(-0.106$ to 0.116$)$ & 0.929 & 0.071 \\
\hline $0_{3}(\mathrm{ppb})$ & $-0.081(-0.258$ to 0.096$)$ & 0.369 & -1.143 \\
\hline $\mathrm{SO}_{2}(\mathrm{ppb})$ & $-0.035(-0.386$ to 0.315$)$ & 0.843 & -0.216 \\
\hline $\mathrm{PM}_{10}\left(\mu \mathrm{g} / \mathrm{m}^{3}\right)$ & $0.031(-0.067$ to 0.129$)$ & 0.536 & 0.588 \\
\hline Black smoke $\left(\mu \mathrm{g} / \mathrm{m}^{3}\right)$ & $0.045(-0.113$ to 0.203$)$ & 0.576 & 0.405 \\
\hline \multicolumn{4}{|l|}{$\mathrm{FVC}(\mathrm{ml}) \mathrm{n}=28$} \\
\hline $\mathrm{NO}_{2}(\mathrm{ppb})$ & $0.071(-0.189$ to 0.332$)$ & 0.591 & 1.000 \\
\hline $\mathrm{O}_{3}(\mathrm{ppb})$ & $0.162(-0.238$ to 0.562$)$ & 0.426 & 2.288 \\
\hline $\mathrm{SO}_{2}(\mathrm{ppb})$ & $-0.335(-1.192$ to 0.522$)$ & 0.444 & -2.043 \\
\hline $\mathrm{PM}_{10}\left(\mu \mathrm{g} / \mathrm{m}^{3}\right)$ & $0.187(-0.017$ to 0.392$)$ & 0.073 & 3.561 \\
\hline Black smoke $\left(\mu \mathrm{g} / \mathrm{m}^{3}\right)$ & $0.166(-0.218$ to 0.551$)$ & 0.396 & 1.498 \\
\hline
\end{tabular}

*In addition to individual pollutants (previous day), each model includes outdoor temperature (average of the minimum and maximum) and season (four categories) plus control for autocorrelation.

†Estimates represent the change in lung function for a 1 unit change in pollutant level (ppb for $\mathrm{NO}_{2}, \mathrm{O}_{3}, \mathrm{SO}_{2} ; \mu \mathrm{g} / \mathrm{m}^{3}$ for $\mathrm{PM}_{10}$, black smoke).

\#Estimates represent the change in lung function for an IQR change in pollutant level. $\mathrm{FEV}_{1}$, forced expiratory volume in $1 \mathrm{~s}$; FVC, forced vital capacity; PEF, peak expiratory flow; $\mathrm{PM}$, particulate matter. 
Table 4 Large PEF decrements, COPD exacerbations and PEF exacerbations*

\begin{tabular}{|c|c|c|c|}
\hline Pollutant & $\begin{array}{l}\text { OR } \dagger \text { (unit change) } \\
(95 \% \mathrm{CI})\end{array}$ & p Value & $\begin{array}{l}\text { Estimate } \ddagger \text { (per } \\
\text { IOR change) }\end{array}$ \\
\hline \multicolumn{4}{|l|}{ Large PEF decrements } \\
\hline $\mathrm{NO}_{2}(\mathrm{ppb})$ & $1.000(0.995$ to 1.004$)$ & 0.844 & 0.994 \\
\hline $\mathrm{O}_{3}(\mathrm{ppb})$ & 0.996 (0.989 to 1.004$)$ & 0.362 & 0.950 \\
\hline $\mathrm{SO}_{2}(\mathrm{ppb})$ & 1.001 (0.988 to 1.014$)$ & 0.890 & 1.006 \\
\hline $\mathrm{PM}_{10}\left(\mu \mathrm{g} / \mathrm{m}^{3}\right)$ & 0.999 (0.995 to 1.003$)$ & 0.712 & 0.985 \\
\hline Black smoke $\left(\mu \mathrm{g} / \mathrm{m}^{3}\right)$ & 1.001 (0.991 to 1.011$)$ & 0.851 & 1.009 \\
\hline \multicolumn{4}{|l|}{ COPD exacerbations } \\
\hline $\mathrm{NO}_{2}(\mathrm{ppb})$ & 1.002 (0.996 to 1.008$)$ & 0.469 & 1.032 \\
\hline $\mathrm{O}_{3}(\mathrm{ppb})$ & $1.005(0.987$ to 1.023$)$ & 0.598 & 1.070 \\
\hline $\mathrm{SO}_{2}(\mathrm{ppb})$ & $1.002(0.982$ to 1.022$)$ & 0.878 & 1.010 \\
\hline $\mathrm{PM}_{10}\left(\mu \mathrm{g} / \mathrm{m}^{3}\right)$ & $1.004(0.998$ to 1.010$)$ & 0.234 & 1.075 \\
\hline Black smoke $\left(\mu \mathrm{g} / \mathrm{m}^{3}\right)$ & $1.003(0.994$ to 1.013$)$ & 0.497 & 1.029 \\
\hline \multicolumn{4}{|l|}{ Symptomatic fall in PEF } \\
\hline $\mathrm{NO}_{2}(\mathrm{ppb})$ & 1.004 (0.999 to 1.009$)$ & 0.137 & 1.058 \\
\hline $0_{3}(\mathrm{ppb})$ & $1.002(0.984$ to 1.020$)$ & 0.840 & 1.026 \\
\hline $\mathrm{SO}_{2}(\mathrm{ppb})$ & $1.004(0.987$ to 1.022$)$ & 0.622 & 1.026 \\
\hline $\mathrm{PM}_{10}\left(\mu \mathrm{g} / \mathrm{m}^{3}\right)$ & $1.006(1.001$ to 1.012$)$ & 0.029 & 1.124 \\
\hline Black smoke $\left(\mu \mathrm{g} / \mathrm{m}^{3}\right)$ & $1.007(1.000$ to 1.014$)$ & 0.050 & 1.066 \\
\hline
\end{tabular}

*In addition to individual pollutants (previous day), each model includes outdoor temperature (average of the minimum and maximum) and season (four categories) plus control for autocorrelation.

†ORs are for a 1 unit change in pollutant level (ppb for $\mathrm{NO}_{2}, \mathrm{O}_{3}, \mathrm{SO}_{2} ; \mu \mathrm{g} / \mathrm{m}^{3}$ for $\mathrm{PM}_{10}$, black smoke).

$¥ 0 \mathrm{Rs}$ are for an IQR change in pollutant level.

COPD, chronic obstructive pulmonary disease; PEF, peak expiratory flow; PM, particulate matter.

1.13; $95 \%$ CI 1.04 to 1.23 ) for a rise in $\mathrm{PM}_{10}$ across its IOR. No other symptom-pollutant combinations were significant, except $\mathrm{O}_{3}$ which showed a protective association with nasal discharge/congestion (table 5).

In multipollutant models, the effect size for $\mathrm{PM}_{10}$ on symptomatic fall in PEF remained similar and borderline significant after adjustment for other pollutants (table 6). In contrast, the effects of $\mathrm{NO}_{2}$ and black smoke were weaker after controlling for $\mathrm{PM}_{10}$. For dyspnoea, the effect of $\mathrm{PM}_{10}$ was slightly stronger and remained significant after adjustment for either $\mathrm{NO}_{2}$, black smoke or both (table 6). There was no evidence of any adverse effect of $\mathrm{NO}_{2}$ or black smoke after allowing for $\mathrm{PM}_{10}$.

\section{DISCUSSION}

Overall this study provided evidence for adverse effects of outdoor pollution on symptoms and exacerbations in patients with COPD living in London, particularly $\mathrm{PM}_{10}$, black smoke and $\mathrm{NO}_{2}$. Most symptoms gave $\mathrm{ORs}>1$ but very few associations were statistically significant. Effect sizes were mostly larger for symptomatic fall in PEF compared with COPD exacerbations and gave significant $\mathrm{ORs}$ for $\mathrm{NO}_{2}, \mathrm{PM}_{10}$ and black smoke. Symptomatic falls in PEF events were more common than COPD exacerbations and so significance is partly due to increased statistical power. Dyspnoea was associated with higher levels of $\mathrm{PM}_{10}$ but was not significantly associated with any other pollutants. Multiple pollutant models showed that the association between $\mathrm{PM}_{10}$ and dyspnoea was stronger after adjustment for other pollutants, although this analysis was post hoc and conducted to aid interpretation of the findings. In general, symptoms are highly variable in COPD and the appearance of shortness of breath on the diary card may reflect psychological as well as mechanical effects on the airway. The occurrence of shortness of breath with a fall in PEF is suggestive of a mechanical effect on the airway by some stimulus.
Table 5 Worsening symptoms: dyspnoea, sputum purulence or sputum amount, nasal discharge/congestion, wheeze or tight chest and upper respiratory symptoms*

\begin{tabular}{|c|c|c|c|}
\hline Pollutant & $\begin{array}{l}\mathrm{OR} \dagger \text { (unit change) } \\
(95 \% \mathrm{CI})\end{array}$ & p Value & $\begin{array}{l}\text { Estimate } \ddagger \text { (per } \\
\text { IQR change) }\end{array}$ \\
\hline \multicolumn{4}{|l|}{ Dyspnoea $\mathrm{n}=77$} \\
\hline $\mathrm{NO}_{2}(\mathrm{ppb})$ & $1.003(0.997$ to 1.008$)$ & 0.338 & 1.036 \\
\hline $0_{3}(\mathrm{ppb})$ & 1.005 (0.995 to 1.016$)$ & 0.335 & 1.078 \\
\hline $\mathrm{SO}_{2}(\mathrm{ppb})$ & $0.996(0.980$ to 1.013$)$ & 0.662 & 0.978 \\
\hline $\mathrm{PM}_{10}\left(\mu \mathrm{g} / \mathrm{m}^{3}\right)$ & $1.006(1.002$ to 1.011$)$ & 0.008 & 1.125 \\
\hline Black smoke $\left(\mu \mathrm{g} / \mathrm{m}^{3}\right)$ & $1.003(0.994$ to 1.012$)$ & 0.526 & 1.027 \\
\hline \multicolumn{4}{|l|}{ Sputum changes $n=68$} \\
\hline $\mathrm{NO}_{2}(\mathrm{ppb})$ & 1.006 (0.999 to 1.013$)$ & 0.085 & 1.085 \\
\hline $\mathrm{O}_{3}(\mathrm{ppb})$ & 1.007 (0.992 to 1.022$)$ & 0.370 & 1.099 \\
\hline $\mathrm{SO}_{2}(\mathrm{ppb})$ & 1.008 (0.988 to 1.029$)$ & 0.446 & 1.042 \\
\hline $\mathrm{PM}_{10}\left(\mu \mathrm{g} / \mathrm{m}^{3}\right)$ & $1.004(0.997$ to 1.011$)$ & 0.251 & 1.082 \\
\hline Black smoke $\left(\mu \mathrm{g} / \mathrm{m}^{3}\right)$ & $1.004(0.992$ to 1.016$)$ & 0.536 & 1.035 \\
\hline \multicolumn{4}{|c|}{ Nasal discharge or congestion $n=70$} \\
\hline $\mathrm{NO}_{2}(\mathrm{ppb})$ & $0.999(0.991$ to 1.006$)$ & 0.690 & 0.979 \\
\hline $0_{3}(p p b)$ & $0.984(0.970$ to 0.998$)$ & 0.023 & 0.794 \\
\hline $\mathrm{SO}_{2}(\mathrm{ppb})$ & $1.011(0.994$ to 1.030$)$ & 0.209 & 1.072 \\
\hline $\mathrm{PM}_{10}\left(\mu \mathrm{g} / \mathrm{m}^{3}\right)$ & $1.003(0.997$ to 1.010$)$ & 0.296 & 1.067 \\
\hline Black smoke $\left(\mu \mathrm{g} / \mathrm{m}^{3}\right)$ & $1.003(0.992$ to 1.013$)$ & 0.598 & 1.026 \\
\hline \multicolumn{4}{|c|}{ Wheeze or tight chest $\mathrm{n}=70$} \\
\hline $\mathrm{NO}_{2}(\mathrm{ppb})$ & 1.002 (0.996 to 1.009$)$ & 0.460 & 1.033 \\
\hline $0_{3}(\mathrm{ppb})$ & $0.992(0.977$ to 1.007$)$ & 0.274 & 0.890 \\
\hline $\mathrm{SO}_{2}(\mathrm{ppb})$ & 1.002 (0.986 to 1.019$)$ & 0.785 & 1.014 \\
\hline $\mathrm{PM}_{10}\left(\mu \mathrm{g} / \mathrm{m}^{3}\right)$ & 1.004 (0.998 to 1.009$)$ & 0.187 & 1.071 \\
\hline Black smoke $\left(\mu \mathrm{g} / \mathrm{m}^{3}\right)$ & $1.002(0.993$ to 1.010$)$ & 0.722 & 1.014 \\
\hline \multicolumn{4}{|c|}{ Upper respiratory symptoms $n=73$} \\
\hline $\mathrm{NO}_{2}(\mathrm{ppb})$ & 0.999 (0.990 to 1.008$)$ & 0.849 & 0.988 \\
\hline $\mathrm{O}_{3}(\mathrm{ppb})$ & $0.987(0.969$ to 1.005$)$ & 0.143 & 0.829 \\
\hline $\mathrm{SO}_{2}(\mathrm{ppb})$ & 0.991 (0.971 to 1.012$)$ & 0.392 & 0.947 \\
\hline $\mathrm{PM}_{10}\left(\mu \mathrm{g} / \mathrm{m}^{3}\right)$ & $1.000(0.993$ to 1.007$)$ & 0.928 & 0.994 \\
\hline Black smoke $\left(\mu \mathrm{g} / \mathrm{m}^{3}\right)$ & $1.007(0.990$ to 1.024$)$ & 0.435 & 1.062 \\
\hline
\end{tabular}

*In addition to individual pollutants (previous day), each model includes outdoor temperature (average of the minimum and maximum) and season (four categories) plus control for autocorrelation.

†ORs are for a 1 unit change in pollutant level ( $\mathrm{ppb}$ for $\mathrm{NO}_{2}, \mathrm{O}_{3}, \mathrm{SO}_{2} ; \mu \mathrm{g} / \mathrm{m}^{3}$ for $\mathrm{PM}_{10}$, black smoke).

$\ddagger$ Rs are for an IQR change in pollutant level.

$\mathrm{PM}$, particulate matter.

When estimated effect sizes were scaled to IOR increases in pollutant level, it was evident that estimated effect sizes were considerable: the odds of a symptomatic fall in PEF increased by $13 \%$ when $\mathrm{PM}_{10}$ increased across the IOR, and a similar size effect was observed for dyspnoea. These increases in odds represent a substantial increase in risk, if associations were real and causal, and are stronger than observed effects of raised pollution on COPD hospital admissions. ${ }^{5}$

Effects on neither mean lung function nor the binary large PEF decrements showed consistent trends, despite evidence from other panels that the binary outcome is more discriminating than mean PEF. ${ }^{24}$ This may reflect the high variability of PEF and/or that lung function was measured after taking medication. Importantly, the findings of adverse effects on symptoms but not mean lung function are consistent with results of ecological studies showing associations with acute events such as death, hospital admission and general practitioner consultations. They lend support to the hypothesis that effects of outdoor air pollution are greater among the very vulnerable.

Findings in this London study were consistent with those of Harré in New Zealand ${ }^{11}$ who reported associations between particles and symptoms with similar effect sizes to ours; however, they also found no associations with lung function. 
Table 6 Further investigation of associations with PEF exacerbations and dyspnoea: single and multiple pollutant models*

\begin{tabular}{|c|c|c|c|c|c|c|c|}
\hline \multirow[b]{2}{*}{ Model* } & \multicolumn{3}{|c|}{ Single pollutant models } & \multicolumn{4}{|c|}{ Multiple pollutant models } \\
\hline & $\begin{array}{l}\text { OR† } \\
\text { (unit change) }\end{array}$ & SE & p Value & $\begin{array}{l}\text { OR† } \\
\text { (unit change) }\end{array}$ & SE & p Value & $\begin{array}{l}\text { OR } \neq \\
\text { (IOR change) }\end{array}$ \\
\hline \multicolumn{8}{|c|}{ Symptomatic fall in PEF $(\mathrm{N}=78)$} \\
\hline \multicolumn{8}{|l|}{ Model 1} \\
\hline $\mathrm{NO}_{2}$ & 1.004 & 0.003 & 0.137 & 0.999 & 0.003 & 0.709 & 0.983 \\
\hline $\mathrm{PM}_{10}$ & 1.006 & 0.003 & 0.029 & 1.007 & 0.003 & 0.042 & 1.140 \\
\hline \multicolumn{8}{|l|}{ Model 2} \\
\hline $\mathrm{NO}_{2}$ & 1.004 & 0.003 & 0.137 & 1.002 & 0.004 & 0.654 & 1.025 \\
\hline Black smoke & 1.007 & 0.004 & 0.050 & 1.005 & 0.005 & 0.306 & 1.049 \\
\hline \multicolumn{8}{|l|}{ Model 3} \\
\hline $\mathrm{PM}_{10}$ & 1.006 & 0.003 & 0.029 & 1.006 & 0.004 & 0.083 & 1.126 \\
\hline Black smoke & 1.007 & 0.004 & 0.050 & 1.000 & 0.005 & 0.953 & 0.998 \\
\hline \multicolumn{8}{|l|}{ Model 4} \\
\hline $\mathrm{NO}_{2}$ & 1.004 & 0.003 & 0.137 & 0.999 & 0.004 & 0.725 & 0.980 \\
\hline $\mathrm{PM}_{10}$ & 1.006 & 0.003 & 0.029 & 1.007 & 0.004 & 0.064 & 1.137 \\
\hline Black smoke & 1.007 & 0.004 & 0.050 & 1.001 & 0.006 & 0.907 & 1.006 \\
\hline \multicolumn{8}{|l|}{ Dyspnoea $\mathrm{n}=77$} \\
\hline \multicolumn{8}{|l|}{ Model 1} \\
\hline $\mathrm{NO}_{2}$ & 1.003 & 0.003 & 0.338 & 0.997 & 0.003 & 0.380 & 1.017 \\
\hline $\mathrm{PM}_{10}$ & 1.006 & 0.002 & 0.008 & 1.008 & 0.003 & 0.007 & 1.031 \\
\hline \multicolumn{8}{|l|}{ Model 2} \\
\hline $\mathrm{NO}_{2}$ & 1.003 & 0.003 & 0.338 & 1.001 & 0.004 & 0.760 & 0.961 \\
\hline Black smoke & 1.003 & 0.005 & 0.526 & 1.003 & 0.006 & 0.598 & 1.159 \\
\hline \multicolumn{8}{|l|}{ Model 3} \\
\hline $\mathrm{PM}_{10}$ & 1.006 & 0.002 & 0.008 & 1.008 & 0.003 & 0.007 & 1.156 \\
\hline Black smoke & 1.003 & 0.005 & 0.526 & 0.996 & 0.006 & 0.455 & 0.961 \\
\hline \multicolumn{8}{|l|}{ Model 4} \\
\hline $\mathrm{NO}_{2}$ & 1.003 & 0.003 & 0.338 & 0.998 & 0.004 & 0.578 & 0.970 \\
\hline $\mathrm{PM}_{10}$ & 1.006 & 0.002 & 0.008 & 1.008 & 0.003 & 0.005 & 1.168 \\
\hline Black smoke & 1.003 & 0.005 & 0.526 & 0.998 & 0.007 & 0.733 & 0.979 \\
\hline
\end{tabular}

Trenga ${ }^{10}$ reported effects of $\mathrm{PM}_{2.5}$ on $\mathrm{FEV}_{1}$ in all adults but no effects on PEF. $\mathrm{PM}_{2.5}$ data were not available when our study was conducted but since $\mathrm{PM}_{10}$ is dominated by small particles, the comparison with our study is reasonable. The adverse effects of $\mathrm{O}_{3}$ on exacerbations demonstrated in the Parisian study ${ }^{12}$ were stronger than in our study.

The estimated relationships between air pollution and symptoms and lung function in this COPD panel may have been affected by the time patients spent outdoors. Subjects recorded this for part of the study only and so, although we did adjust, full adjustment was not possible.

When this study was designed we chose to limit the use of multiple pollutant metrics to avoid overtesting. In particular we used just one measure for $\mathrm{NO}_{2}-1 \mathrm{~h}$ maximum-partly because of the belief that the peak drives health effects. However, the correlation between $1 \mathrm{~h}$ maximum $\mathrm{NO}_{2}$ and average daily $\mathrm{NO}_{2}$ was very high at 0.90 , and so the choice would seem unlikely to matter. When our study was conducted, there was a network of black smoke monitors and so we used the monitor nearest to the patient's home to estimate their exposure. The data on the other pollutants all came from a single monitor in central London but the correlation with another monitor for $\mathrm{PM}_{10}$ was high (0.95), suggesting that this was not unreasonable. Even so, the use of multiple monitors may explain the weaker associations observed with black smoke. We modelled exposure to pollution using previous day pollutant level as others have done, and have not looked at long lags ${ }^{25}$ which would most probably have produced stronger associations.

Daily diary data provide a powerful tool tool to investigate effects of air pollution within individuals but are resource intensive and often panels are only able to include a relatively small sample and/or a short follow-up time. The strength of this study was the relatively large sample, 94, and the lengthy 2-year follow-up period. Since compliance was very good, missing data were minimal.

Recent WHO guidelines for $\mathrm{PM}_{10}$ are 20 and $50 \mu \mathrm{g} / \mathrm{m}^{3}$ for annual and daily averages, respectively. The levels of exposure for this panel were a little higher. The WHO guidelines were largely based on ecological time series studies and cohort data on mortality. This study therefore lends support to the guideline.

In conclusion, in patients with COPD living in London, there is evidence for adverse effects of outdoor pollution on symptoms and exacerbations, particularly for $\mathrm{PM}_{10}$, black smoke and $\mathrm{NO}_{2}$. The ORs of up to 1.17 for an IOR increase in pollutant level represent substantial effects which would have important public health implications if shown to be real and causal. This deserves further investigation in larger panels.

Funding The East London COPD study was funded by the British Lung Foundation. The statistical analysis for the air pollution analyses was funded by the UK Department of Health. 


\section{Competing interests None.}

Ethics approval This study was conducted with the approval of the East London and City Health Authority Ethic Committee.

Provenance and peer review Not commissioned; externally peer reviewed.

\section{REFERENCES}

1. Murray CJ, Lopez AD. Mortality by cause for eight regions of the world: Global Burden of Disease Study. Lancet 1997;349:1269-76.

2. Logan WPD. Mortality in London fog incident. Lancet 1953;1:336-8.

3. Schwartz J, Marcus A. Mortality and air-pollution in London: a time-series analysis. Am J Epidemiol 1990;131:185-94.

4. Anderson HR, Ponce de Leon A, Bland JM, et al. Air pollution and daily mortality in London: 1987-92. BMJ 1996;312:665-9.

5. Anderson HR, Spix C, Medina S, et al. Air pollution and daily admissions for chronic obstructive pulmonary disease in 6 European cities: results from the APHEA project. Eur Respir J 1997;10:1064-71.

6. Lawther PJ, Waller RE, Henderson M. Air pollution and exacerbations of bronchitis. Thorax 1970;5:525-39.

7. Higgins BG, Francis HC, Yates CJ, et al. Effects of air pollution on symptoms and peak expiratory flow measurements in subjects with obstructive airways disease. Thorax 1995;50:149-55.

8. van der Zee SC, Hoek G, Boezen MH, et al. Acute effects of air pollution on respiratory health of 50-70 yr old adults. Eur Respir J 2000;15:700-9.

9. Lagorio S, Forastiere F, Pistelli R, et al. Air pollution and lung function among susceptible adult subjects: a panel study. Environ Health 2006:5:11.

10. Trenga CA, Sullivan JH, Schildcrout JS, et al. Effect of particulate air pollution on lung function in adult and pediatric subjects in a Seattle panel study. Chest 2006:129:1614-22.

11. Harre ES, Price PD, Ayrey RB, et al. Respiratory effects of air pollution in chronic obstructive pulmonary disease: a three month prospective study. Thorax 1997:52:1040-4.

12. Desqueyroux $\mathbf{H}$, Pujet JC, Prosper $M$, et al. Effects of air pollution on adults with chronic obstructive pulmonary disease. Arch Environ Health 2002;57:554-60.
13. Seemungal TA, Donaldson GC, Paul EA, et al. Effect of exacerbation on quality of life in patients with chronic obstructive pulmonary disease. Am J Respir Crit Care Med 1998; 157:1418-22

14. Seemungal TA, Donaldson GC, Bhowmik A, et al. Time course and recovery of exacerbations in patients with chronic obstructive pulmonary disease. Am J Respir Crit Care Med 2000:161:1608-13.

15. Seemungal TA, Harper-Owen R, Bhowmik A, et al. Detection of rhinovirus in induced sputum at exacerbation of chronic obstructive pulmonary disease. Eur Respir J 2000;16:677-83.

16. Bhowmik A, Seemungal TA, Sapsford RJ, et al. Relation of sputum inflammatory markers to symptoms and lung function changes in COPD exacerbations. Thorax 2000;55:114-20.

17. American Thoracic Society. Standards for the diagnosis and care of patients with chronic obstructive pulmonary-disease. Am J Respir Crit Care Med 1995;152 S77-121.

18. British Thoracic Society. Guidelines for the management of chronic obstructive pulmonary disease. Thorax 1997:52:S1-12.

19. Pitkin AD, Roberts CM, Wedzicha JA. Arterialized earlobe blood-gas analysis -an underused technique. Thorax 1994;49:364-6.

20. Anthonisen NR, Warren CPW, Nelson NA, et al. Antibiotic therapy and chronic obstructive pulmonary disease-response. Ann Intern Med 1987;107:597.

21. Buck SF. A method of estimation of missing values in multivariate data suitable for use with an electronic computer. $R$ Stat Soc (B) 1960:22:302-6.

22. Peacock JL, Symonds $P$, Jackson $P$, et al. Acute effects of winter air pollution on respiratory function in schoolchildren in southern England. Occup Environ Med 2003:60:82-9.

23. Scarlett JF, Abbott KJ, Peacock JL, et al. Acute effects of summer air pollution on respiratory function in primary school children in southern England. Thorax 1996:51:1109-14.

24. Hoek G, Dockery DW, Pope A, et al. Association between PM10 and decrements in peak expiratory flow rates in children: reanalysis of data from five panel studies. Eur Respir J 1998;11:1307-11.

25. Stylianou M, Nicolich MJ. Cumulative effects and threshold levels in air pollution mortality: data analysis of nine large US cities using the NMMAPS dataset. Environ Pollut 2009:157:2216-23.

\section{Journal club}

\section{Inactivation of the N-terminal of ACE reduces bleomycin-induced lung fibrosis}

This study examined bleomycin-induced lung injury in normotensive mice, termed $\mathrm{N}-\mathrm{KO}$ and $\mathrm{C}-\mathrm{KO}$, which have point mutations inactivating the $\mathrm{N}$ - or C-terminal catalytic sites of angiotensin converting enzyme (ACE), respectively. N-KO, but not C-KO mice, exhibited a marked resistance to bleomycin-induced lung injury and fibrosis, as assessed by lung histology and hydroxyproline content (46\% increase in hydroxyproline content in C-KO lungs compared with $6.9 \%$ in $\mathrm{N}-\mathrm{KO}$ lungs, $\mathrm{p}<0.001)$. Furthermore, the $\mathrm{N}-\mathrm{KO}$ mice showed enhanced survival when exposed to a dose of bleomycin lethal to wild-type mice. The importance of the tetrapeptide $\mathrm{N}$-acetyl-seryl-aspartyl-lysyl-proline (AcSDKP), an ACE $\mathrm{N}$-terminal substrate, was demonstrated when N-KO mice were treated with S-17092, a prolyl-oligopeptidase inhibitor that reduces the concentration of AcSDKP. These mice developed lung fibrosis similar to wild-type mice in response to bleomycin injection. Conversely, the administration of AcSDKP to wild-type mice reduced bleomycin-induced lung fibrosis, as assessed by lung hydroxyproline content $(7.7 \mu \mathrm{g} / \mathrm{mg}$ in mice given AcSDKP compared with $12.47 \mu \mathrm{g} / \mathrm{mg}$ in mice given saline, $\left.\mathrm{p}<10^{-4}\right)$.

These results show that the inactivation of the N-terminal of ACE significantly reduces bleomycin-induced lung fibrosis and implicates AcSDKP as a mediator of this protection. A novel means to increase tolerance to bleomycin and to treat fibrosing lung diseases is thus proposed.

- Li P, Xiao HD, Xu J, et al. Angiotensin-converting enzyme N-terminal inactivation alleviates bleomycin-induced lung injury. Am J Pathol 2010;177:1113-21.

\section{S Haque}

Correspondence to S Haque, Foundation Year 2 Doctor, King George Hospital, Essex, IG3 8YB, UK; shariahhaque@doctors.org.uk

Published Online First 26 October 2010

Thorax 2011;66:596. doi:10.1136/thx.2010.151894 